\title{
Estimating mercury emissions resulting from wildfire in forests of the Western United States
}

\author{
Jackson P. Webster ${ }^{1 *}$, Tyler J. Kane ${ }^{2}$, Daniel Obrist ${ }^{3}$, Joseph N. Ryan ${ }^{1}$, George R. Aiken ${ }^{2}$
}

${ }^{1}$ Civil, Environmental and Architectural Engineering, University of Colorado at Boulder, UCB 428, Boulder, CO 80309-0428.

${ }^{2}$ U.S. Geological Survey, 3215 Marine St, Bldg 6, Boulder, CO 80309.

${ }^{3}$ Desert Research Institute, Division of Atmospheric Sciences, 2215 Raggio Parkway, Reno, NV, 89512.

*Corresponding author: email: Jackson.webster@ colorado.edu; phone: 530-258-7549 


\begin{abstract}
Understanding the emissions of mercury $(\mathrm{Hg})$ from wildfires is important for quantifying the global $\mathrm{Hg}$ cycle. Emissions of $\mathrm{Hg}$ from soils resulting from wildfires in the Western United States was estimated for the 2000 to 2013 period, and the potential emission of $\mathrm{Hg}$ from forest soils was assessed as a function of forest type and soil-heating. Wildfire released an annual average of $3100 \pm 1900 \mathrm{~kg}-\mathrm{Hg} \mathrm{y}^{-1}$ for the years spanning 2000-2013 in the 11 states within the study area. This estimate is nearly 5 -fold lower than previous estimates for the study region. Lower emission estimates are attributed to an inclusion of fire severity within burn perimeters. Within reported wildfire perimeters, the average distribution of low, moderate, and high severity burns was 52, 29, and $19 \%$ of the total area, respectively. Review of literature data suggests that that low severity burning does not result in soil heating, moderate severity fire results in shallow soil heating, and high severity fire results in relatively deep soil heating $(<5 \mathrm{~cm})$. Using this approach, emission factors for high severity burns ranged from 58-640 $\mu \mathrm{g}-\mathrm{Hg} \mathrm{kg-fuel}{ }^{-1}$. In contrast, low severity burns have emission factors that are estimated to be only $18-34 \mu \mathrm{g}-\mathrm{Hg} \mathrm{kg-}$ fuel $^{-1}$. In this estimate, wildfire is predicted to release 1-30 $\mathrm{g} \mathrm{Hg} \mathrm{ha}^{-1}$ from Western United States forest soils while above ground fuels are projected to contribute an additional 0.9 to $7.8 \mathrm{~g}$ $\mathrm{Hg} \mathrm{ha}^{-1}$. Land cover types with low biomass (desert scrub) are projected to release less than $1 \mathrm{~g}$ $\mathrm{Hg} \mathrm{ha}^{-1}$. Following soil sources, fuel source contributions to total $\mathrm{Hg}$ emissions generally followed the order of duff $>$ wood $>$ foliage $>$ litter $>$ branches.
\end{abstract}

Keywords: Western North America Mercury Synthesis; WNAMS; soil mercury; fire severity; soil heating; FOFEM 


\section{Introduction}

Transport and deposition of $\mathrm{Hg}$ from natural and anthropogenic sources has led to its enrichment in surficial soils throughout the geosphere (Driscoll et al., 2013). This pool of $\mathrm{Hg}$ can be transported into surface waters and sediments, and potentially be converted into methylmercury (MeHg), a potent neurotoxin that impairs global fisheries and poses risk to ecosystems and human health (Selin et al., 2007; Poulin and Gibb, 2008; Driscoll et al., 2013). One of the major sources of $\mathrm{Hg}$ to the global atmospheric pool is the mobilization of $\mathrm{Hg}$ during biomass burning (Friedli et al., 2009; Pirrone et al., 2010; Driscoll et al., 2013).

Forest soils are effective at sequestering atmospherically-deposited $\mathrm{Hg}$. The sequestration of $\mathrm{Hg}$ has led to a 15-20\% increase in the content of $\mathrm{Hg}$ in forest soils around the globe over the last century (Grigal, 2003; Selin, 2009; Driscoll et al., 2013). The transfer of Hg into forest soils occurs when gaseous $\mathrm{Hg}\left(\mathrm{Hg}^{0}\right)$ is taken up, mainly by leaf stomata, and transferred to the forest floor through litterfall (St. Louis et al., 2001; Rea et al., 2000, 2001; Obrist, 2007; Rutter et al., 2011; Demers et al., 2013; Jiskra et al., 2015). Once at the ground surface, Hg is subsequently transferred to the soil column during degradation of litter materials (St. Louis et al., 2001; Rea et al., 2002; Obrist et al., 2011; Pokharel and Obrist, 2011). Hg that is transferred into the soil column is strongly correlated with soil organic matter (SOM; Grigal et al., 2003; Engle et al., 2006; Biswas et al., 2007; Obrist et al., 2011). The correlation between Hg and SOM is due to the formation of strong bonds between $\mathrm{Hg}$ and reduced organic sulfur moieties within the organic matter (Xia et al., 1999; Skyllberg et al., 2000; Skylberg et al., 2006). Temperate forests

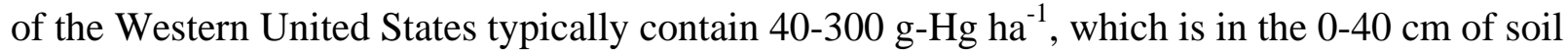
(>90\%), the forest floor (litter and duff layers), and above-ground biomass (Obrist, 2012).

Wildfire has the potential to mobilize $\mathrm{Hg}$ from biomass, O-horizon soil (organic soil of litter and duff) and A-horizon soil (shallow mineral soils), but not from the C-horizon (deeper mineral soil) (Friedli et al., 2001; Friedli et al., 2003; Engle et al., 2006; Wiedinmyer and Friedli, 2007; Obrist et al., 2007; Biswas et al., 2007, 2008; Burke et al., 2010; Woodruff and Cannon, 2012).

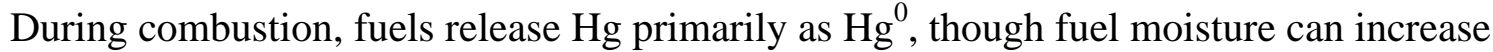
particulate Hg (PHg) emissions (Friedli et al., 2003; Obrist et al., 2007). Hg bound by the soil matrix begins to thermally desorb at $150^{\circ} \mathrm{C}$ (Biester and Scholz, 1996) and soil $\mathrm{Hg}$ has been shown to be re-emitted during wildfire if sufficient soil heating takes place (Biswas et al., 2007; 
2008; Woodruff and Cannon, 2012). The extent to which wildfire liberates $\mathrm{Hg}$ from each reservoir (canopy, fuel bed, soil) depends on the severity of burning (Biswas et al., 2007). The severity of burning is a product of the intensity and duration of the fire and depends on available fuel, ambient temperature, and relative humidity, canopy structure, forest health, wind speed, and many other potential factors (Parsons, 2003; Neary et al., 2005; Certini, 2005; Keely, 2009). A low-severity fire may only minimally consume the canopy, have low flame height and burn scars, and result in minimal duff consumption leaving duff layers intact (Parsons, 2003; Neary et al., 2005; Certini, 2005; Keely, 2009). High-severity burns can result in combustion of the entire litter load, a large portion of the organic horizon, and a large fraction of the crown foliage (Parsons, 2003; Neary et al., 2005; Certini, 2005; Keely, 2009). In addition, the depth of soil heating is a function of fire severity at the soil surface. For instance, a low burn intensity fire coupled with a long duration, such as a smoldering log, may transfer more heat to soil than a high-intensity, short-duration event, such as a chaparral fire (Parsons, 2003). Heat is quickly dissipated below the soil surface due to the insulating properties of soil and the presence of soil moisture (Certini, 2005). A fire burning at $850^{\circ} \mathrm{C}$ on the surface will generally not raise the subsurface temperature beyond $150^{\circ} \mathrm{C}$ below $5 \mathrm{~cm}$ (Debano, 2000). Within the strong thermal gradient, it is likely that soil only reaches temperatures of $200-300^{\circ} \mathrm{C}$ (Certini, 2005).

As part of the Western North American Mercury Synthesis (WNAMS) effort, the goal of this study was to synthesize data on $\mathrm{Hg}$ emissions resulting from wildfires, and analyze these data in the context of $\mathrm{Hg}$ distribution and fire occurrence within the 11 Western States including Arizona, California, Colorado, Idaho, Montana, New Mexico, Nevada, Oregon, Utah, Washington, and Wyoming. In the Western States, warming air-temperatures have led to increasing occurrence and severity of wildfire (Westerling et al., 2006; Littell et al., 2009; Westerling et al., 2014). Additionally, the practice of fire exclusion from the early 1900's on has increased fuel-loading, altering fire behavior in some areas (Miller et al., 2009). Large-scale wildfire disturbance in forests of the Western States will likely lead to greater release of $\mathrm{Hg}$, especially if forests with long fire recurrence intervals begin burning at increased rates. Within the Western States, forest types, fuels, and fire behaviors can vary across ecotypes; however, there is currently no assessment of how forest type and severity may influence the release of $\mathrm{Hg}$ during wildfire. This study provides spatial detail on $\mathrm{Hg}$ release during fire by developing a 
model that illustrates the potential for future emissions during high-severity burning and historical emissions from the region using burn severity mapping.

Literature review of $\mathrm{Hg}$ losses resulting from wildfires in the Western United States.

There are very few laboratory studies that have examined $\mathrm{Hg}$ emission during combustion of fuels from forests of the Western United States. Using litter fuels from a mixture of plant species common to the Western United States, Friedli et al. (2003) reported that the litter released $98 \%$ of the initial $\mathrm{Hg}$ during combustion. Using measurements of gaseous $\mathrm{Hg}^{0}$ and $\mathrm{CO} / \mathrm{CO}_{2}$ within a laboratory plume and emission factors (EF; ratio of $\mathrm{Hg}$ emitted to biomass consumed) of 14$18 \mu \mathrm{g}-\mathrm{Hg} \mathrm{Kg}-$ fuel $^{-1}$ were determined for green conifer branches and dry litter, respectively. These laboratory measurements were then compared to wildfire by measuring $\mathrm{Hg}^{0}$, and $\mathrm{CO} / \mathrm{CO}_{2}$ as a surrogate for biomass combustion, in the smoke plume of a burning boreal Spruce forest in Ontario, Canada, where an EF of $112 \mu \mathrm{g}-\mathrm{Hg} \mathrm{kg}_{\mathrm{fuel}}{ }^{-1}$ was determined. Friedli et al. (2003) attributed discrepancies between lab and field measurements to soil-derived $\mathrm{Hg}$ released during heating in the field. In a second study using fuels collected from Western United States locations, Obrist et al. (2007) observed that the moisture content of the fuels greatly influenced the fraction of particulate $\mathrm{Hg}(\mathrm{PHg})$ released. Dry fuels emitted almost no PHg, while moist fuels emitted nearly half of the total $\mathrm{Hg}$ as $\mathrm{PHg}$. In a study of $\mathrm{Hg}$ release from soils during furnace heating, Biswas et al. (2007) measured gaseous $\mathrm{Hg}^{0}$ from bulk soil collected from 0-10 $\mathrm{cm}$ depth that were subject to temperatures increasing at a rate of $1^{\circ} \mathrm{C} \sec ^{-1}$ from $25^{\circ} \mathrm{C}$ to $800^{\circ} \mathrm{C}$. $\mathrm{Hg}$ loss from the soil began at $180^{\circ} \mathrm{C}$, which compares well with previous studies reporting that desorption begins at $150^{\circ} \mathrm{C}$ from soils containing atmospherically deposited $\mathrm{Hg}$ bound by soil humics (Biester and Scholtz, 1997). Biswas et al. (2007) also reported that heating at a moderate temperature $\left(180^{\circ} \mathrm{C}\right)$ for $1 \mathrm{~h}$ and $4 \mathrm{~h}$ resulted in $56 \%$ and $91 \%$ of $\mathrm{Hg}$ being lost from soil, respectively. Considering both temperature and duration of heating suggests that prolonged heating, even at moderate temperatures $\left(<200^{\circ} \mathrm{C}\right)$ is likely to cause $\mathrm{Hg}$ release to the atmosphere from soil.

There are a limited number of field-based studies of $\mathrm{Hg}$ emissions during wildfires conducted in the Western United States. In a study of the northeastern Sierra Nevada, Engle et al. (2006) reported $\mathrm{Hg}$ losses from Ponderosa pine forests and a desert location with sagebrush cover during wildfire and prescribed fire. Engle et al. (2006) classified soil as containing a litter layer and an A-horizon; there is no mention of a separate duff (decomposed litter) layer. The litter 
layer was found to release $>90 \%$ of the associated $\mathrm{Hg}$, but there was no loss of $\mathrm{Hg}$ measured from underlying soils. To derive areal estimates for emissions during wildfires and prescribed fires, it was assumed that anywhere from $0-100 \%$ of $\mathrm{Hg}$ may be lost from the upper $5 \mathrm{~mm}$ of Ahorizon soil. Using these estimates, combined with fuel consumption and litter $\mathrm{Hg}$ concentrations, Engle et al. (2006) suggested emissions of 2.2-4.9 g- Hg ha ${ }^{-1}$ for wildfire and 2.0$5.1 \mathrm{~g}-\mathrm{Hg} \mathrm{ha}{ }^{-1}$ prescribed fire sites containing Ponderosa pine forest. At a non-forested location with desert sagebrush cover, losses of $0.36 \mathrm{~g}-\mathrm{Hg} \mathrm{ha}^{-1}$ were reported.

Biswas et al. (2007) collected soil cores from forests (Lodgepole, Spruce, Douglas fir, Aspen) and meadow locations to investigate the role of wildfire severity on $\mathrm{Hg}$ losses from the top $8 \mathrm{~cm}$ of soil. Severity was delineated using the guidelines of Parsons (2003). Through comparison with unburned locations, burned soils were found to be depleted in $\mathrm{Hg}$ to depths of approximately $4 \mathrm{~cm}$ below the burned soil surface. Losses of soil $\mathrm{Hg}$ from conifer forests were estimated at $7.4 \mathrm{~g}-\mathrm{Hg} \mathrm{ha}^{-1}$ in low-severity burns, $21 \mathrm{~g}-\mathrm{Hg} \mathrm{ha}^{-1}$ in moderate-severity burns, and 23 and $28 \mathrm{~g}-\mathrm{Hg} \mathrm{ha}^{-1}$ in high-severity burns. Aspen forests released 3.6 and $12 \mathrm{~g}-\mathrm{Hg} \mathrm{ha}^{-1}$ from lowand moderate-severity burns, respectively. Biswas et al. (2008) reported on $\mathrm{Hg}$ release caused by low-, medium-, and high-severity burning in a conifer forest containing Ponderosa pine, Lodgepole pine, Subalpine fir and Whitebark pine. Similar to their previous study, burned soils were depleted in $\mathrm{Hg}$ to about $4 \mathrm{~cm}$ below the combusted soil layer. Unlike the previous study, $\mathrm{Hg}$ release was not correlated to the severity of burning and it was estimated that $6.7 \pm 2.5 \mathrm{~g}-\mathrm{Hg} \mathrm{ha}^{-1}$ were released from the soil regardless of burn severity.

The only study of western land covers that did not include any conifer forest was conducted by Burke et al. (2010) who collected soil cores from three watersheds with chaparral cover in southern California. Cores were collected to $10 \mathrm{~cm}$ depth in $2.5 \mathrm{~cm}$ increments. They found losses of $\mathrm{Hg}$ in the surficial soil increment $(<2.5 \mathrm{~cm})$ during chaparral fire.

A modeling effort to quantify $\mathrm{Hg}$ emissions from North American wildfire for the years 20022006 was carried out by Wiedinmyer and Friedli (2007). In the 11 states within the WNAMS project area, emissions between 2002 and 2006 were estimated at $14,700 \mathrm{~kg}-\mathrm{Hg} \mathrm{y}^{-1}$ based on the sum of monthly averages in each of the 11 states for 2002-2006 (Wiedinmyer and Friedli, 2007, SI). Data for the Hg emission modeling were estimated for boreal forest, temperate forest, sagebrush-chaparral, and grasslands using data from Friedli et al. (2001; 2003), Engle et 
al.(2006), Biswas et al. (2007; 2008), and other studies from outside the WNAMS project area that included Brunke et al. (2000) and Cinnirella and Pirrone (2006). Wiedinmyer and Friedli (2007) averaged all of the previously reported $\mathrm{Hg}$ emissions to create a single average EF for land-cover classes. An average $\mathrm{EF}$ for $\mathrm{Hg}$ was determined from measured soil $\mathrm{Hg}$ losses and estimating $25,000 \mathrm{~kg} \mathrm{ha}^{-1}$ of fuel at forested locations. In temperate forests, the average lower bound $\mathrm{EF}$ was $120 \mu \mathrm{g}-\mathrm{Hg} \mathrm{kg}$-biomass ${ }^{-1}$ and the average upper bound was $340 \mu \mathrm{g}-\mathrm{Hg} \mathrm{Kg}-$ biomass $^{-1}$. The mean of all studies value was $240 \mu \mathrm{g}-\mathrm{Hg} \mathrm{kg-biomass}{ }^{-1}$. To apply the EFs to wildfire in the United Sates, fire occurrence was determined by satellite imagery (MODIS). Fuel loading was determined by assigning a total biomass load to the type of land cover obtained from the Global Land Cover 2000 data set (Wiedinmyer et al., 2006). The estimated fuel consumption value was multiplied by the $\mathrm{EF}$ and the area burned by wildfire to produce $\mathrm{Hg}$ loss estimates. It is clear that there are both above- and below-ground losses of $\mathrm{Hg}$ during wildfire. Aboveground sources include combusting canopy (leaves, needles, branches, and bark) and surface materials (woody debris, litter, and soil duff) and the below ground source is heated soil. Dry fuels will lose nearly all of the associated $\mathrm{Hg}$ in the form of $\mathrm{Hg}^{0}$, while moist fuels, including fresh leaves and needles, may have a larger contribution of PHg. If soil heating from fuel combustion at the forest floor generates temperatures above $150^{\circ} \mathrm{C}$, soil $\mathrm{Hg}$ will be emitted, although not all studies have reported such losses due to sampling methods that may be too course to detect small changes in upper soil pools. The duration of heating will increase release of soil $\mathrm{Hg}$. In this paper, $\mathrm{Hg}$ emissions from soils resulting from wildfires in the Western United States for the 2000 to 2013 period were estimated and the potential emission of $\mathrm{Hg}$ from these soils as a function of forest type and soil-heating were assessed.

\section{Methods}

\subsection{Description of data sources}

To generate spatial $\mathrm{Hg}$ emission estimates from soil, a combination of published data and modeling software was used. Detailed spatial data of soil Hg concentrations, forest types, soil densities were combined with past fire perimeters and fire severities throughout the Western United States using geospatial datasets in ArcGIS (ESRI, version 10.2). Fuel consumption estimates and thermal profiles were generated in soil for major forest types under different burn severities using First Order Fire Effects Model (FOFEM; Reinhardt et al., 1997; Lutes, 2012). 
Spatial soil Hg concentrations were interpolated from data provided by a recent large-scale sampling campaign conducted by the U.S. Geological Survey (Smith et al., 2013). This campaign included 4857 sampling points located across the contiguous United States with 1911 of these included in the Western States region delineated in this study. For each sampling location, soil $\mathrm{Hg}$ concentrations were measured in the top $5 \mathrm{~cm}$, the A-horizon, and the Chorizon. For this study, only the $0-5 \mathrm{~cm}$ depth was considered, as this is most likely to be affected by heating (Certini, 2005). Within the WNAMS project boundaries, soil $\mathrm{Hg}$ concentration data points were interpolated into a raster file with a $25 \mathrm{~km}$ spatial resolution using an inverse distance weighting (IDW) technique (ArcGIS, ESRI, version 10.2). For a discussion on $\mathrm{Hg}$ distribution, see Obrist et al. 2016 (this issue). To decrease the bias of contaminated sites, a filter was applied to exclude 7 points with concentrations greater than $800 \mathrm{ng} \mathrm{g}^{-1}$ before interpolation. The resulting raster was in a projection with angular units (WGS 1984), and it was resampled and projected (NAD 1983 Albers, linear units) to a raster with a $10 \mathrm{~km}$ spatial resolution using a bilinear interpolation (Figure 1; ArcGIS, ESRI, version 10.2).

A soil density layer was obtained from the CONUS-Soil, 1-km Multi-Layer Soil Characteristics dataset (Miller and White, 1998). A forest-type GIS layer was generated from a list of North American tree species digitized at $25 \mathrm{~km}$ resolution by Thompson et al. (1999). Forest type definitions and distributions are summarized in Table 1 and illustrated on Figure 2. Shrub cover types, including sagebrush and chaparral, were not included because the soil heating model used for this analysis does not predict soil heating for these land cover types.

The depth at which the soil temperature reaches $150^{\circ} \mathrm{C}$ was determined for moderateand high-severity burns for each forest type using FOFEM for each of the dominant forest type GIS polygons. FOFEM predicts fuel

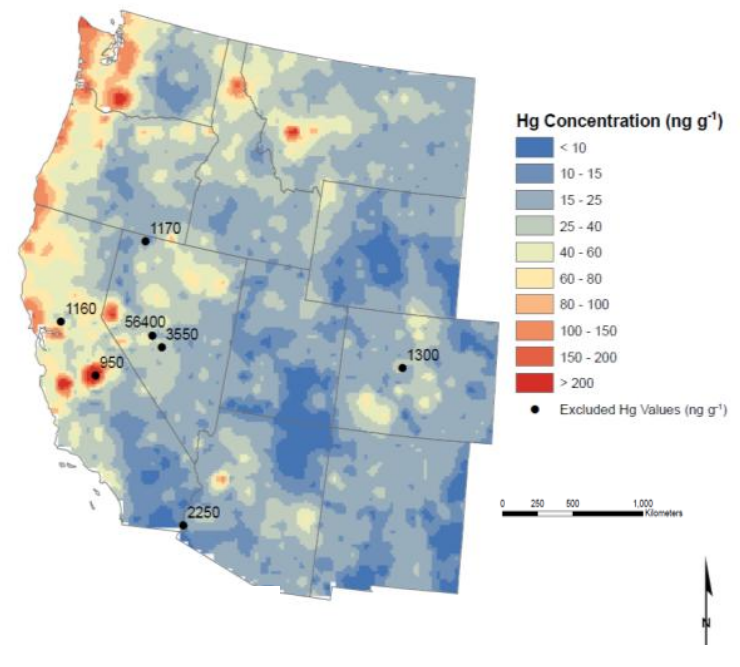

Figure 1: Interpolated soil $\mathrm{Hg}$ concentrations in the 0-5 $\mathrm{cm}$ depth for 11 states in the Western United States. Data obtained from Smith et al. (2013). All data points over $800 \mathrm{ng} \mathrm{g}^{-1}$ were excluded and are shown as black dots on the map. 
consumption, soil temperature, depth of heating, and smoke emissions during wildfire based on an extensive database of fuel loading scenarios by forest type (Reinhardt et al., 1997; Lute et al., 2013). Soil heating (Table 2) and fuel consumption estimates were generated by selecting typical fuel loading scenarios in the model. Fuels were assigned a $\mathrm{Hg}$ concentration (Table 3). Soil moisture scenarios were selected (moderate, dry, and very dry) as a master variable to account for depth of heating and fuel consumption as a function of fire severity. All modelling scenarios were run using the "SAF/SRM" cover types. Within the model, moderate, dry, and very dry settings change the percent of moisture in duff, fuel, and soil. The modeled duff moistures can range from $20-75 \%$, fuel moistures range from $6-30 \%$, and soil moistures range

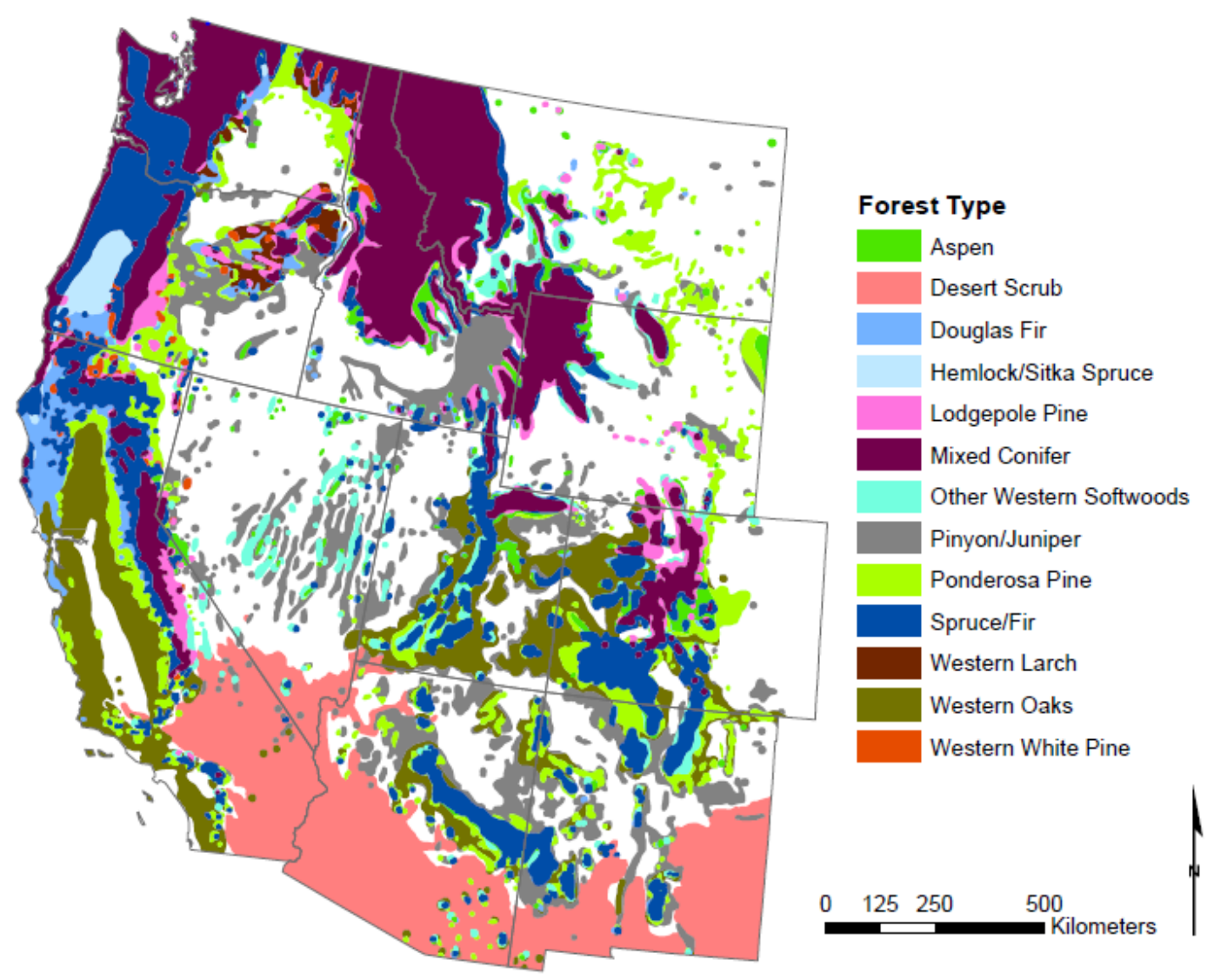

Figure 2: Distribution of forest types throughout the Western United States. The unshaded background is nonforested land. Data were obtained from Thompson et al. (1999).

from 5 to $15 \%$ by weight from moderate to very dry. 
The severity of wildfire is subjective and is defined differently for above- and below-ground effects, though they are related. Above-ground burn severity was delineated by visual indices such as canopy loss and flame-height-indicators and below ground severity was defined as the duration and intensity of heating, which may be identified through soil depth loss and ash color (Keeley, 2009). In this effort, above-ground severity was identified through the monitoring trends in burn severity data base (MTBS; Eidenshank et al., 2007) and it was assumed that in areas delineated as high-severity burns by MTBS had greater ground fuel loss, duff loss, and soil heating. This approach links two independent definitions of severity to determine a predicted depth of soil heating. "Very dry" conditions were used to represent high-severity burning, and “dry" conditions for moderate-severity burning. Moist soils are not predicted to undergo heating and were not considered to be a source of $\mathrm{Hg}$ emission. The soil heating depths for individual species obtained from FOFEM were averaged when multiple species were present in a single location. Soil heating depths estimated for moderate- and high-severity burns were appended to the attribute table of the forest type feature. Due to predicted fuel consumption and soil heating, a high-severity fire will release more $\mathrm{Hg}$ than a moderate one in the same forest type, so it is important to differentiate between areas of varying severity within a single burn area. To account for variation in burn severity within burn perimeters, we used burn severity data obtained from the MTBS database. Analysts assess dNBR thresholds to delineate burn severity within a fire perimeter. The MTBS database is therefore subject to analyst interpretation, but provides the best available areal estimates for burn severity. Each MTBS raster image is a mosaic containing fires from a single year, which have been split into four levels of burn severity: unburned, low, moderate, and high (Figure 3). The ArcGIS software procedure was to adjust the MTBS pixel resolution from $30 \mathrm{~m}$ to $90 \mathrm{~m}$ using the "nearest neighbor" method and then each MTBS raster image was converted to an array of points (one point per pixel, on center). 


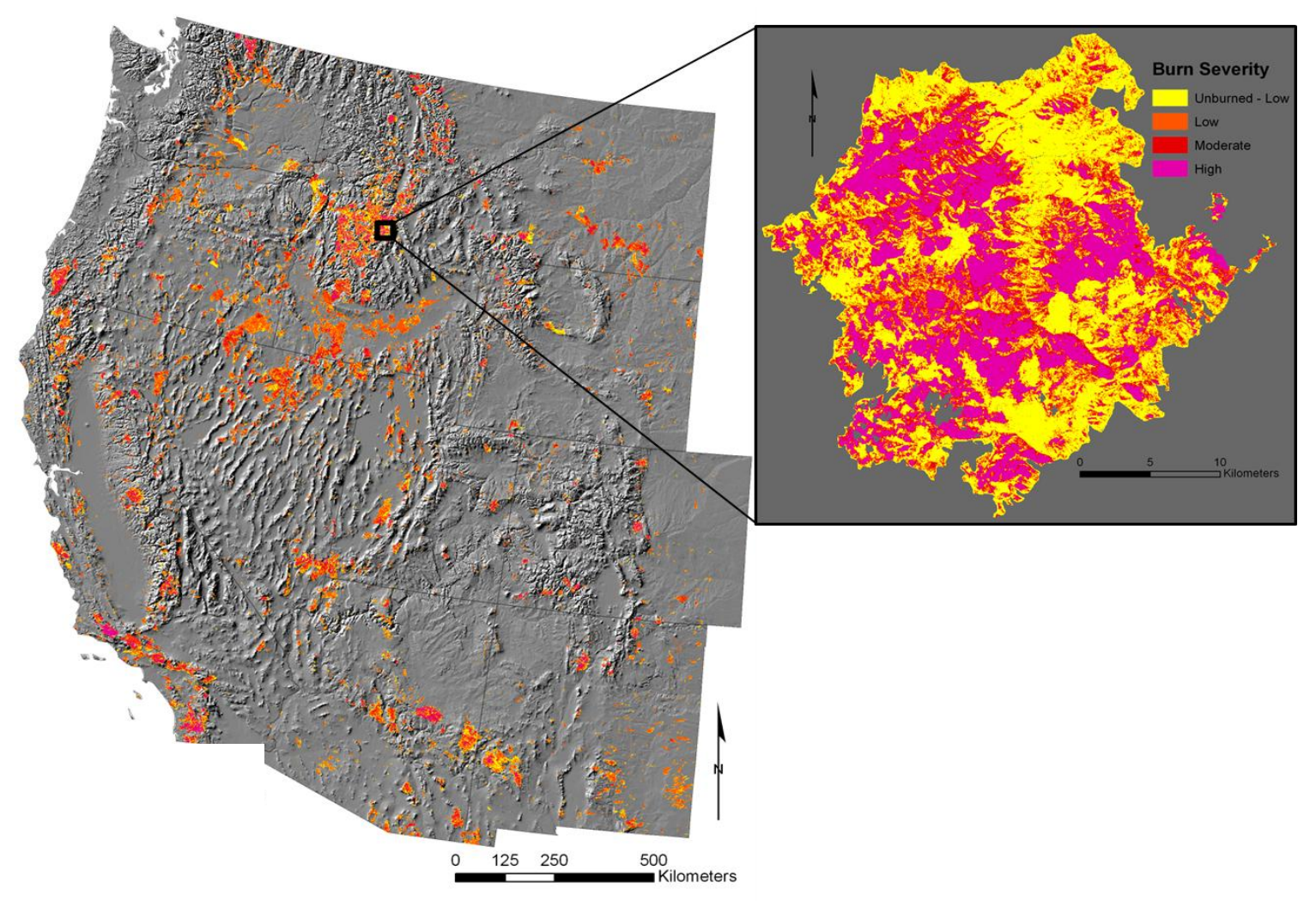

Figure 3: Perimeters of wildfires occurring in the western United States 2000-2013. The expanded section is an example of the distribution of severity within a fire perimeter. Data obtained from Monitoring Trends in Burn Severity (MTBS; Eideshank et al., 2007). 
Table 2: First Order Fire Effects Model estimated depths at which the soil temperature is reaches $150^{\circ} \mathrm{C}$ during a fire event.

\begin{tabular}{|ccc|}
\hline Forest Type & $\begin{array}{c}\text { Moderate } \\
\text { Severity } \\
\text { Depth }(\mathbf{c m})\end{array}$ & $\begin{array}{c}\text { High } \\
\text { Severity } \\
\text { Depth }(\mathbf{c m})\end{array}$ \\
\hline Aspen & 1.5 & 2 \\
\hline Desert Scrub & 0 & 0.5 \\
\hline Douglas Fir & 2.5 & 4 \\
\hline Hemlock/Sitka & 0.5 & 2.5 \\
Spruce & & \\
\hline Lodgepole Pine & 2 & 4.5 \\
\hline Mixed Conifer & 2 & 4 \\
\hline Other Western & 3 & 4 \\
Softwoods & & \\
\hline Pinyon/Juniper & 1 & 1.5 \\
\hline Ponderosa Pine & 2 & 2.5 \\
\hline Spruce/Fir & 1 & 3 \\
\hline Western Larch & 2.5 & 4.5 \\
\hline Western Oaks & 0 & 0 \\
\hline Western White Pine & 0.5 & 2.5 \\
\hline
\end{tabular}

Table 3: Mercury concentrations in forest fuel components from the Western United States (Obrist et al., 2011; 2015).

\begin{tabular}{cccccc}
\hline $\begin{array}{c}\text { Sample } \\
\text { Type }\end{array}$ & $\begin{array}{c}\# \\
\text { Observations }\end{array}$ & \multicolumn{5}{l}{ Hg concentrations $\left(\boldsymbol{\mu g ~ k g} \mathbf{~}^{-\mathbf{1}}\right)$} \\
\hline & & Mean & $\begin{array}{r}\text { Std } \\
\text { Dev. }\end{array}$ & Min. & Max. \\
\hline Conifer & & & & & \\
Leaves & 56 & 28 & 16 & 6.7 & 64 \\
\hline Deciduous & & & & & \\
Leaves & 17 & 19 & 16 & 7.8 & 50 \\
\hline Branches & 44 & 26 & 28 & 0.7 & 160 \\
\hline Litter & 8 & 34 & 14 & 22 & 66 \\
\hline Duff & 8 & 85 & 49 & 46 & 200 \\
\hline
\end{tabular}

\subsection{Estimating soil Hg emissions from 2000-2013}

The annual mass of soil $\mathrm{Hg}$ emitted by fire for the years 2000-2013 $\left(M_{H g}\right)$ was estimated as the sum total after solving the following equation of each pixel in the study region:

$$
M_{H g}=\sum \frac{1}{2} D_{150}[H g] \rho_{\text {soil }} A_{\text {pixel }} N_{\text {pixel }} \quad \text { (Eqn. 1) }
$$

Where $D_{150}$ represents the depth (m) at which the temperature of the soil during a fire event is equal to $150^{\circ} \mathrm{C},[\mathrm{Hg}]$ is the soil $\mathrm{Hg}$ concentration $\left(\mu \mathrm{g} \mathrm{kg}^{-1}\right), \rho_{\text {soil }}$ is soil density $\left(\mathrm{kg} \mathrm{m}^{-3}\right), A_{\text {pixel }}$ is the pixel area $\left(\mathrm{m}^{2}\right)$ burned within a specific year, and $N_{\text {pixel }}$ is the total number of pixels of one raster image. The equation is multiplied by one-half to estimate $100 \%$ loss at the heated surface and $0 \%$ loss at $\mathrm{D}_{150}$. At every MTBS point location, the pixel values of the soil density raster and $\mathrm{Hg}$ concentration raster were extracted and added to the MTBS point attribute table. Finally, the MTBS and forest-type feature classes were spatially joined, such that their attribute tables were linked wherever they intersected geographically. The result is a list of points representing MTBS pixels for a given year, where each point corresponds to a single location with a specific burn severity, soil density, $\mathrm{Hg}$ concentration, forest type, and depth of heating to $150^{\circ} \mathrm{C}$. Finally, Eqn. 1 was used to calculate the mass of soil $\mathrm{Hg}$ emitted by fire each year.

\subsection{Mapping soil Hg emission potential}

The upper boundary for potential $\mathrm{Hg}$ emissions throughout the Western United States was estimated by modelling fuel consumption and soil heating across all forest types under highseverity burning conditions only. This study approached the soil $\mathrm{Hg}$ emission calculation 
similarly to the ArcGIS methods for the historical estimates. First, the Hg concentration raster was converted to an array of points (one point per pixel, on center). At every point location, soil density pixel values were extracted and added to the attribute table of the $\mathrm{Hg}$ concentration points. The forest type layer was spatially joined to the $\mathrm{Hg}$ concentration points, such that a forest type and a depth of soil heating to $150^{\circ} \mathrm{C}$ were assigned to each point in the $\mathrm{Hg}$ concentration attribute table. All points in non-forested areas were removed, and the remaining points were converted back to a raster format using an inverse distance weighted interpolation. Finally, Eqn. 1 was used to calculate the total mass of soil $\mathrm{Hg}$ that could be released during a high severity fire in every forested pixel in the Western United States.

\subsection{Estimating above-ground losses}

To estimate the amount of $\mathrm{Hg}$ released from above ground fuel, the total consumed mass of fuels was estimated using FOFEM (Lutes, 2012). For each moisture condition the fuel consumption predicted by FOFEM was recorded and multiplied by the fuel loss estimate by the estimated $\mathrm{Hg}$ concentration (Table 3) the mass of $\mathrm{Hg}$ released from fuels by forest type. Fuel consumption under moderate-moisture conditions was used to estimate duff and litter losses during lowseverity burns.

\section{Results and Discussion}

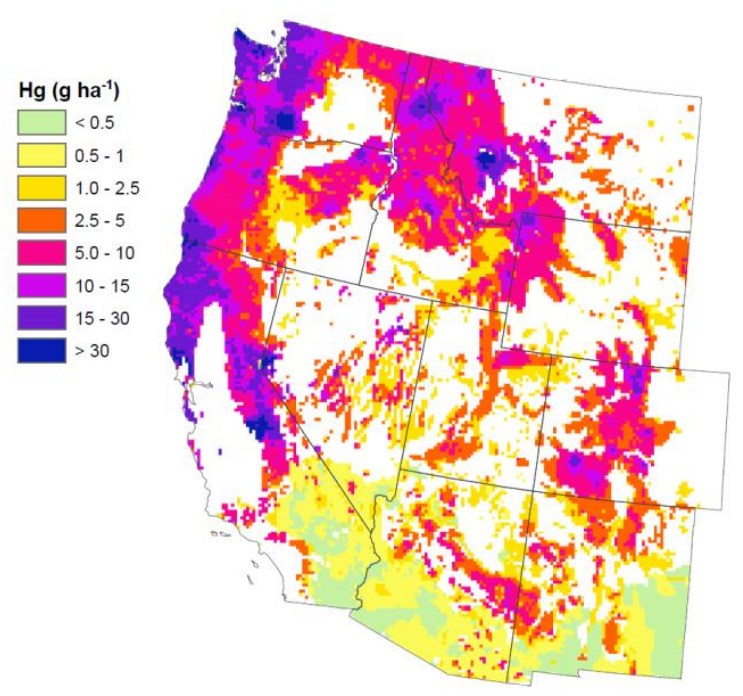




\subsection{Hg emissions during past years}

$\mathrm{Hg}$ emissions during wildfires for the
Figure 4. Predicted mass of soil mercury available for fire-driven emission during high-severity burning in the Western United States.

Western United States spanning the years 2000-2013 were estimated using Eqn. 1 and the MTBS database (Figure 5). Annual emissions ranged from $660-7000 \mathrm{~kg}-\mathrm{Hg} \mathrm{y}^{-1}$ and the average and standard deviation for annual emissions was $3300 \pm 2100 \mathrm{~kg}-\mathrm{Hg} \mathrm{y}^{-1}$. The substantial interannual variability in the estimated emissions appear to be mainly a result of fire occurrence during the years studied. In comparison with the area burned area delineated in the MTBS data base (Figure 3) it appears that years with low emissions correspond to lower total area burned and also with a greater percentage of low-severity burns. Years with higher $\mathrm{Hg}$ emissions had greater total area burned and a greater high-severity percentage. The estimate of $3300 \mathrm{~kg}-\mathrm{Hg} \mathrm{\textrm {y } ^ { - 1 }}$ is almost 5-fold lower than the 14,700 $\mathrm{kg} \mathrm{Hg} \mathrm{y}^{-1}$ estimated by Wiedinmyer and Friedli (2007) for the 11 Western states within the WNAMS project boundary between 2002 and 2006. The $\mathrm{Hg}$ emission estimate of Wiedinmyer and Friedli (2007) is over 2-fold the highest estimate presented in the current study. There does not appear to be bias in the comparison due to fire occurrence and behavior in temporally overlapping range of the studies. The average area burned between 2002 and 2006 is within $1 \%$ difference of the 2000-2013 average. The severity distributions are 48,32 , and $20 \%$ for the years 2002-2006 and 52, 29, and 19\% for 2000-2013 for low, moderate, and high severity burn area, respectively. The lower emission estimates in the current study are attributed to the consideration of burn severity within burn perimeters using the MTBS GIS layer (Figure 3). Low-severity fires are not predicted to cause enough soil heating to release $\mathrm{Hg}$ from soil, so they only emit $\mathrm{Hg}$ from fuel. These results influence the selection of an appropriate EF for making $\mathrm{Hg}$ estimates. Because only $19 \%$ of the total area was classified as high severity, only this fraction will have a high soil $\mathrm{Hg}$ contribution and corresponding high EF. Accordingly, moderate-severity burn EFs are expected to fall within the low- and high-EF bounds.

Accounting for fire severity greatly reduces the estimated emission of $\mathrm{Hg}$ from a fire perimeter and reveals that about half of annual emissions are generated during fuel combustion, while the other half is due to soil heating (Figure 5).

\subsection{Potential emissions during high severity burning}

The modeling efforts conducted resulted in a map of potential areal emissions of $\mathrm{Hg}$ for the Western United States during high severity burns (Figure 4). The estimates presented in the current study ranged from $<0.01 \mathrm{~g}-\mathrm{Hg} \mathrm{ha}{ }^{-1}$ to greater than $100 \mathrm{~g}-\mathrm{Hg} \mathrm{ha}^{-1}$, although nearly all 
(92\%) of the forested locations are within 0.5 and $30 \mathrm{~g}-\mathrm{Hg} \mathrm{ha}^{-1}$. The small percentage (5\%) of area that was modeled to release more than $30 \mathrm{~g}-\mathrm{Hg} \mathrm{ha}^{-1}$ is believed to be an artifact from localized sites with contamination. Emission factors for high severity burns ranged from 58-640 $\mu \mathrm{g}-\mathrm{Hg} \mathrm{kg-fuel}{ }^{-1}$. In contrast, low severity burns have emission factors that are estimated to be

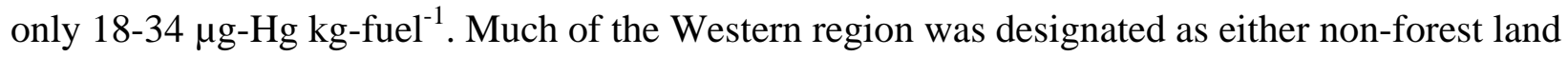
(e.g., agriculture) or fell into a cover type that did not generate soil heating (western oak, grassland, sagebrush, and chaparral). Areas without a release estimate primarily include the Central Valley and southern coastal regions of California, much of the Great Basin in Nevada, and the high plains along the eastern boundary of the study area. The presented emission estimates are likely to be low, because it was not possible to estimate losses in these areas. The land cover type most likely to cause the estimates to be low is the western oak cover type, which represents some regions with frequent fire occurrence such as southern California and Western Colorado (Figure 2).

Estimates for maximum $\mathrm{Hg}$ release during burning corresponds to soil $\mathrm{Hg}$ concentration distribution and forest type (Figures $1 \& 2$ ). Areas of the Western United States that are predicted to release the most $\mathrm{Hg}$ during burning are the coastal region from central California to northern Washington, the northern Sierra Nevada, the Rocky Mountains in Colorado, Wyoming, Idaho, and Montana. The area with the highest release estimates are also the areas with the highest measured soil Hg (Smith et al., 2013; Figure 1). Productive forests transfer greater amounts of $\mathrm{Hg}$ to the soil column and generate greater fuel loads (Obrist et al., 2016); therefore, it follows that wildfires in these areas can result in greater releases of $\mathrm{Hg}$. Regions with high $\mathrm{Hg}$ accumulation also tend to be areas that burn less frequently. The predicted maximum soil emissions are within the bounds of previously reported soil $\mathrm{Hg}$ pools for multiple forest types across the United States. For instance, Obrist (2012) reported soil Hg in the 0-40 $\mathrm{cm}$ depth of Jeffrey pine and Spruce forests to contain approximately $40 \mathrm{~g}-\mathrm{Hg} \mathrm{ha}^{-1}$. This pool size varies regionally, as they also reported Douglas fir soils of the Pacific Northwest to contain $235 \mathrm{~g}-\mathrm{Hg} \mathrm{ha}{ }^{-1}$. The estimates of 0.5 to $30 \mathrm{~g}-\mathrm{Hg} \mathrm{ha}^{-1}$ release from soil appear to be reasonable for the top few centimeters or 5-10\% of the soil column. It is expected that the amount of $\mathrm{Hg}$ released is not predicted by just the depth (i.e. $10 \%$ of the soil column depth does not equal $10 \%$ of the soil $\mathrm{Hg}$ pool), because $\mathrm{Hg}$ concentrations are greater closer to the ground surface (Biswas et al., 2007; Obrist et al., 2011). 
Table 4: Hg emitted from fuels on an areal basis and the percentage of contribution from each fuel component. Wood refers to all size classes of material $>1 / 4$ inch on the forest floor.

\begin{tabular}{|c|c|c|c|c|c|c|c|c|c|c|c|c|}
\hline & $\frac{\Xi}{0}$ & 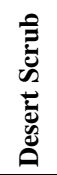 & 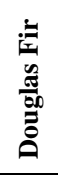 & 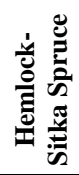 & 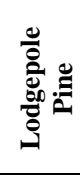 & 总离 & 总 & 范 & 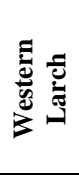 & 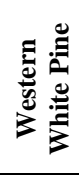 & 苞 & 离 \\
\hline $\begin{array}{l}\text { Hg emitted } \\
\left.\qquad \mathrm{g} \mathrm{ha}^{-1}\right)\end{array}$ & 0.9 & 0.0 & 2.1 & 7.8 & 3.1 & 1.3 & 1.5 & 5.6 & 2.1 & 6.4 & 3.5 & 3.3 \\
\hline Duff & 77 & 0 & 69 & 64 & 68 & 94 & 64 & 76 & 69 & 66 & 71 & 72 \\
\hline Wood & 16 & 0 & 13 & 35 & 18 & 0 & 10 & 17 & 13 & 29 & 22 & 24 \\
\hline Litter & 7 & 100 & 2 & 1 & 2 & 6 & 7 & 1 & 2 & 1 & 2 & 1 \\
\hline Foliage & 0 & 0 & 13 & 0 & 8 & 0 & 18 & 5 & 13 & 3 & 4 & 3 \\
\hline Branch & 0 & 0 & 3 & 0 & 3 & 0 & 1 & 1 & 3 & 1 & 1 & 1 \\
\hline
\end{tabular}

Estimated maximum $\mathrm{Hg}$ emissions from combusted fuel and biomass ranged from 0.9 to $7.8 \mathrm{~g}$ $\mathrm{Hg} \mathrm{ha}^{-1}$ across the major forest types (Table 4). The range in values represents predicted fuel and biomass consumption only, because the $\mathrm{Hg}$ concentrations in litter, duff, and foliage for the Western United States are assumed to be the same for each forest type and region (Table 4;

Obrist et al., 2011, 2016). It is acknowledged that this assumption introduces substantial uncertainty, but it is not currently possible to assess the $\mathrm{Hg}$ content of fuel on a spatial scale that is comparable with soil estimates, because there are no available spatial data on $\mathrm{Hg}$ concentrations in fuels across the Western States. The presented fuel based $\mathrm{Hg}$ emission estimates are well within the upper bounds for above-ground $\mathrm{Hg}$ pool sizes that might be mobilized during wildfire. Specifically, in Ponderosa pine, Douglas fir, and Spruce-fir forests, the estimates of 1.5, 2.1 and $5.6 \mathrm{~g}-\mathrm{Hg}$ ha $^{-1}$ fall below the total above ground pool size given by Obrist (2012) who reported these forest types may contain 2.6 and 2.9 (pine in California, Nevada), 9.0, and $53.3 \mathrm{~g} \mathrm{Hg} \mathrm{ha}^{-1}$, respectively. Predicted losses appear to be reasonable, as not all forest materials containing $\mathrm{Hg}$ are fully combusted during wildfire. 
Using the concentrations of $\mathrm{Hg}$ in fuels (Table 3 ) and assuming combustion of all fuels yielded EFs of 84, 34, 26, and $28 \mu \mathrm{g}-\mathrm{Hg}$ $\mathrm{kg}_{\text {-fuel }}{ }^{-1}$ for duff, litter, branches and leaves, respectively. An EF based on fuel is similar to the $18 \mu \mathrm{g}-\mathrm{Hg} \mathrm{kg}$-fuel ${ }^{-1}$ reported by Friedli et al. (2003) for Ponderosa pine litter. Using areal biomass consumption estimates from FOFEM, and considering the predicted contribution of fuel and soil $\mathrm{Hg}$ emitted during wildfire for the mixed conifer forest yielded EFs ranging from 58 to $640 \mu \mathrm{g}-\mathrm{Hg}$ $\mathrm{kg}$-fuel ${ }^{-1}$. This range is within the bounds of previous upper and lower estimates for mixed conifer temperate forests which have been estimated to range from 54 to $1000 \mu \mathrm{g}-\mathrm{Hg}$ kg-fuel $^{-1}$ (Wiedinmyer and Friedli, 2007). The similar EFs give confidence that these soil contributions adequately represent the sources of $\mathrm{Hg}$ emissions during wildfire.
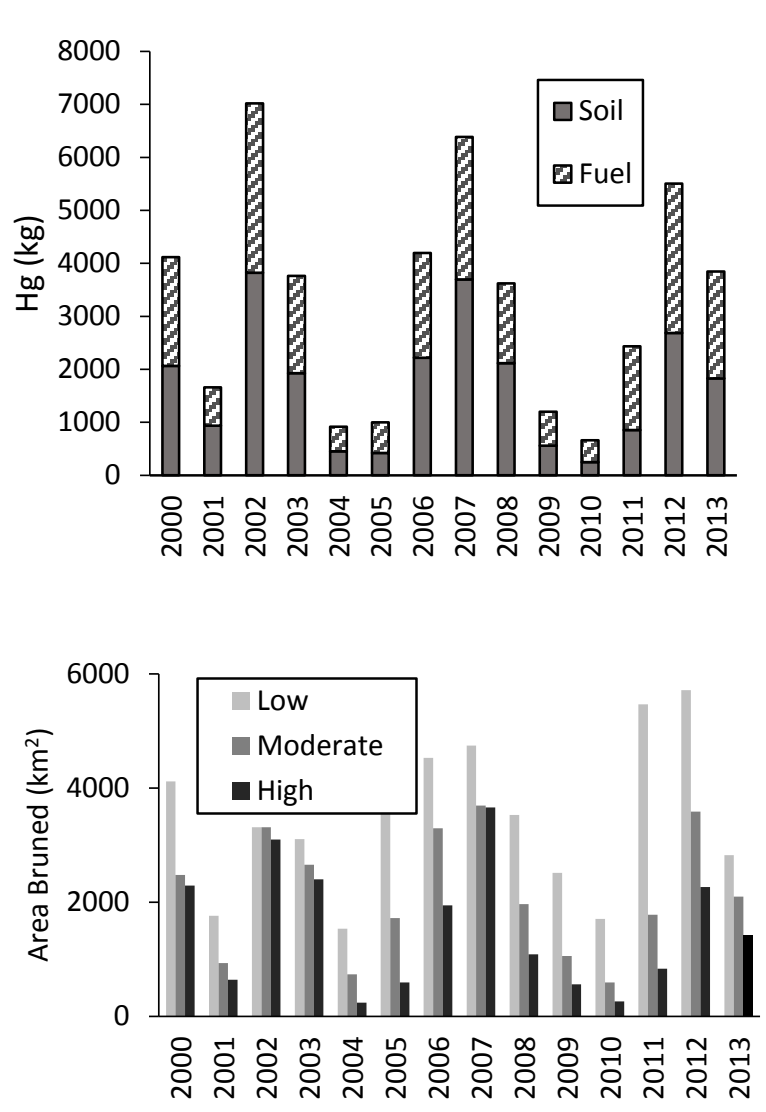

Figure 5: (top) Estimated $\mathrm{Hg}$ emissions from soil and fuel for years 2000-2013 and (bottom) total area burned by severity class for each year. Severity data obtained from Monitoring Trends in Burn Severity (MTBS; Eideshank et al., 2007).

\subsection{Limitations of estimates}

There are a few areas of uncertainty that cannot be reconciled with this modeling approach. Most importantly, FOFEM provides only point data for a single hypothetical location within a forest type. In extrapolating this single point to large spatial areas across the Western United States, it is assumed that the forest type throughout the area is homogeneous. Forests are inherently heterogeneous and differences in aspect, elevations, slope, stand age, canopy density, understory growth, and many more local features can influence fire behavior. Therefore, it is assumed that the values being used represent an overall average when applied across large scales. Second, there is some discrepancy among soil layers and characteristics. For instance, in the national geochemical soil survey (Smith et al., 2013), soil was collected from three layers identified in the field as the $0-5 \mathrm{~cm}$ depth, the A-horizon, and the C-horizon. The 0-5 cm depth 
is measured from the top of first depth able to support root systems. Similarly, FOFEM predicts heating to a certain depth, but it is not possible to link the specific character of the soil in that depth. In both cases, the depth could correspond to either an organic or mineral soil layer. The exact relationship between the soil density GIS layer and depth at which the soil $\mathrm{Hg}$ was measured is not known. Third, uncertainty exists in the use of a single $\mathrm{Hg}$ concentration for the soil horizon referred to as the duff layer. Applying a single $\mathrm{Hg}$ concentration to the duff layer appears to over-simplify the soil horizons. For instance, Obrist et al. (2011) described the surficial soil as composed of $\mathrm{O}_{\mathrm{i}}, \mathrm{O}_{\mathrm{e}}$, and $\mathrm{O}_{\mathrm{a}}$ layers representing fresh, partially decomposed, and fully decomposed (humus) litter layers. In well-humidified soils, $\mathrm{Hg}$ concentrations can be two orders of magnitude greater than that of the litter layer (Obrist et al., 2011; Pokheral and Obrist, 2011). Because there are no integrated spatial datasets on the relative depths of these layers or the $\mathrm{Hg}$ concentration gradients in soil for the forest types in the Western States, the lowest duff concentrations were used for a more conservative $\mathrm{Hg}$ emission estimate. Because duff is the largest fuel source of $\mathrm{Hg}$ during combustion, using higher numbers may greatly increase the estimated release. Fourth, the average $\mathrm{Hg}$ concentrations used for canopy biomass appears to have a log-normal distribution, thus the arithmetic mean used may be a slight over estimation of the actual distribution, which is likely better represented by a geometric mean. Fifth, there was no accounting for how forest stressors might change the emissions of Hg. For instance, the pine beetle infestation across the west has affected tens of millions of hectares of forest and is expected to result in increased fuel and increasing fire severity (Hicke et al., 2012). Of particular concern are forests with large above-ground $\mathrm{Hg}$ pools such as Spruce-fir and Lodgepole forest (Obrist, 2012), where increased severity could potentially liberate much greater amounts of $\mathrm{Hg}$ than what is currently predicted.

\subsection{Implications of potential and reconstructed $\mathrm{Hg}$ emissions by wildfires across the Western U.S. study area}

The results of this study provide important insights for the current understanding Hg emissions during wildfire. First, the sources of $\mathrm{Hg}$ emissions within forest systems were illustrated and clarified that there are both fuel and soil sources. There are some discrepancies in regards to soils as a source of $\mathrm{Hg}$ in previous studies, and this study highlights the importance of soils as potential sources for $\mathrm{Hg}$ emissions during wildfire because fuel $\mathrm{Hg}$ pools are typically much 
lower than soil $\mathrm{Hg}$ pools. Use of typical fuel consumption estimates from 12 forest types, detailed $\mathrm{Hg}$ concentration data from Western soils, and the available fuel $\mathrm{Hg}$ concentrations, demonstrate that soil sources must be included to obtain the EF values reported in the literature.

Furthermore, EF values need to be carefully evaluated in emission modeling, because $\mathrm{Hg}$ release is not proportional to biomass consumption but instead release is tied closely to the degree of subsurface heating.

Second, the role of fire severity within burn perimeters to constrain current emissions estimates was considered. This resulted in much lower average annual $\mathrm{Hg}$ emission estimates than have been previously reported, and this is largely due to the majority of burn perimeters that burn at low severity. It was predicted that the areas subject to high-severity burning generate greater $\mathrm{Hg}$ emissions than those subject to low-severity burning, which is primarily due to the depth of subsurface heating. Because fire severity plays a major role in the release of $\mathrm{Hg}$ from soil, the current trend of increasing wildfire severity in the Western United States is predicted to increase $\mathrm{Hg}$ emissions. Areas that burn infrequently are predicted to have the highest potential for future wildfire releases. These areas include mountainous and coastal regions with high deposition and accumulation (Smith et al., 2013; Nation Atmospheric Deposition Program, 2015). Although burning is infrequent in these regions due to precipitation and snowpack, current warming trends could eventually lead to increasing fire occurrence in some of these areas (Westerling et al., 2014).

Lastly, a complex interplay of factors that determine $\mathrm{Hg}$ emissions during wildfire was found that includes forest type, soil $\mathrm{Hg}$ concentration, fuel loads, soil density, and fire severity; however, these factors cannot be uncoupled. For example, soil $\mathrm{Hg}$ concentration is linked to some degree to forest type, the geographic distribution of forest type is linked to moisture, which is coupled to biomass production, and together these factor influence $\mathrm{Hg}$ deposition and retention on the landscape. Because of this complexity, there was not one single variable that drove the predictions to a greater degree than another variable.

\section{Acknowledgements}

This work was conducted as a part of the Western North American Mercury Synthesis Working Group supported by the John Wesley Powell Center for Analysis and Synthesis, funded by the U.S. Geological Survey. Support was also provided by the U.S. Geological Survey (USGS) 
National Research and Toxic Substances Hydrology Programs and a grant from the National Science Foundation (EAR-0952068). Additionally, we would like to thank the Environmental Protection Agency, Region-10, for providing additional funding for GIS data management through the Regional Applied Research Effort (RARE) program. We also greatly appreciate the GIS statistical support from Mike Tate and Michelle Lutz (USGS, Wisconsin). Any use of trade, firm, or product names is for descriptive purposes only and does not imply endorsement by the U.S. Government

\section{References}

Biester, H., Scholz, C., 1996. Determination of mercury binding forms in contaminated soils: Mercury pyrolysis versus sequential extractions. Environmental Science \& Technology 31, 233-239.

Biswas, A., Blum, J. D., Keeler, G. J., 2008. Mercury storage in surface soils in a central Washington forest and estimated release during the 2001 Rex Creek Fire. Science of the Total Environment 404, 129-138.

Biswas, A., Blum, J. D., Klaue, B., Keeler, G. J., 2007. Release of mercury from Rocky Mountain forest fires. Global Biogeochemical Cycles 21, 1-13.

Brunke, E. G., Labuschagne, C., \& Slemr, F. (2001). Gaseous mercury emissions from a fire in the Cape Peninsula, South Africa, during January 2000. Geophysical Research Letters, 28(8), 1483-1486.

Burke, M. P., Hogue, T. S., Ferreira, M., Mendez, C. B., Navarro, B., Lopez, S., Jay, J. A., 2010. The effect of wildfire on soil mercury concentrations in Southern California watersheds. Water Air and Soil Pollution 212, 369-385.

Certini, G., 2005. Effects of fire on properties of forest soils: A review. Oecologia 143, 1-10.

Cinnirella, S., Pirrone, N., 2006. Spatial and temporal distributions of mercury emissions from forest fires in Mediterranean region and Russian federation. Atmospheric Environment 40, 7346-7361.

DeBano, L. F., 2000. The role of fire and soil heating on water repellency in wildland environments: A review. Journal of Hydrology 231, 195-206.

Demers, J. D. , Blum, J. D., Zak, D. R., 2013. Mercury isotopes in a forested ecosystem: Implications for air-surface exchange dynamics and the global mercury cycle. Global Biogeochemical Cycles 27, 222-238

Driscoll, C. T., Mason, R. P., Chan, H. M., Jacob, D. J., Pirrone, N., 2013. Mercury as a global pollutant: Sources, pathways, and effects. Environmental Science \& Technology 47, 4967-4983.

Eidenshink, J., Schwind, B., Brewer, K., Zhu, Z., Quayle, B., Howard, S., 2007, A project for monitoring trends in burn severity, Fire Ecology 3, 3-21

Engle, M. A., Gustin, M. S., Johnson, D. W., Murphy, J. F., Miller, W. W., Walker, R. F., Wright, J. W., Markee, M., 2006. Mercury distribution in two Sierran forest and one desert sagebrush steppe ecosystems and the effects of fire. Science of the Total Environment 367, 222-233. 
Friedli, H. R., Arellano, A. F., Cinnirella, S., Pirrone, N., 2009. Initial estimates of mercury emissions to the atmosphere from global biomass burning. Environmental Science \& Technology 43, 3507-3513.

Friedli, H. R., Radke, L. F., Lu, J. Y., 2001. Mercury in smoke from biomass fires. Geophysical Research Letters 28, 3223-3226.

Friedli, H. R., Radke, L. F., Prescott, R., Hobbs, P. V., Sinha, P., 2003. Mercury emissions from the August 2001 wildfires in Washington State and an agricultural waste fire in Oregon and atmospheric mercury budget estimates. Global Biogeochemical Cycles 17, 1039, doi:10.1029/2002GB001972.

Grigal, D. F., 2003. Mercury sequestration in forests and peatlands. Journal of Environmental Quality 32, 393-405.

Hicke, J. A., Johnson, M. C., Hayes, J. L., Preisler, H. K., 2012. Effects of bark beetle-caused tree mortality on wildfire. Forest Ecology and Management 271, 81-90.

Hynes, A. J., Donohoue, D. L., Goodsite, M. E., Hedgecock, I. M., 2009. Our current understanding of major chemical and physical processes affecting mercury dynamics in the atmosphere and at the air-water/terrestrial interfaces, in: Pirrone, N., Mason, R.P. (Eds.), Mercury Fate and Transport in the Global Atmosphere. Springer US, pp. $427-$ 457.

Jiskra M., Wiederhold, J. G., Skyllberg, U., Kronberg, R. M. , Hajdas, I., Kretzschmar, R., 2015. Mercury deposition and re-emission pathways in boreal forest soils investigated with $\mathrm{Hg}$ isotope signatures. Environmental Science \& Technology 49, 7188-7196.

Keeley, J. E., 2009. Fire intensity, fire severity and burn severity: a brief review and suggested usage. International Journal of Wildland Fire 18, 116-126.

Littell, J. S., McKenzie, D., Peterson, D. L., Westerling, A. L., 2009. Climate and ecoprovince fire area burned in Western U.S. ecoprovinces, 1916-2003. Ecological Applications 19, $1003-1021$

Lutes, D. 2012. FOFEM 6.0 user guide. Available online: http://firelab.org/sites/default/files/images/downloads/FOFEM6_Help_May12014.pdf. Accessed 23 January 2016.

Miller, D.A., White, R.A., 1998. A Conterminous United States Multi-Layer Soil Characteristics Data Set for Regional Climate and Hydrology Modeling. Earth Interactions 2, 1-26

Miller, J.D., Safford, H.D., Crimmins, M., Thode, A.E., 2009. Quantitative evidence for increasing forest fire severity in the Sierra Nevada and Southern Cascades Mountains, California and Nevada, USA. Ecosystems 12, 16-32.

National Atmospheric Deposition Program, 2015. National Atmospheric Deposition Program 2014 Annual Summary. NADP Data Report 2015-01. Illinois State Water Survey, University of Illinois at Urbana-Champaign, IL. Available online: http://nadp.sws.uiuc.edu/lib/data/2014as.pdf. Accessed 23 January 2016.

Neary, D. G., Ryan, K. C., DeBano, L. F., 2005. Wildland fire in ecosystems: Effects of fire on soils and water. General Technical Report, RMRS-GTR-42-vol, 4, Ogden, UT: USDA Forest Service, Rocky Mountain Research Station. 250 p. Available online: http://www.fs.fed.us/rm/pubs/rmrs_gtr042_4.pdf. Accessed 23 January 2016.

Obrist D., 2007. Atmospheric mercury pollution due to losses of terrestrial carbon pools? Biogeochemistry 85, 119-123 
Obrist, D., 2012. Mercury distribution across 14 US forests. Part II: Patterns of methyl mercury concentrations and areal mass of total and methyl mercury. Environmental Science \& Technology 46, 5921-5930.

Obrist, D., Johnson, D. W., Lindberg, S. E., Luo, Y., Hararuk, O., Bracho, R., Battles, J. J., Dail, D. B., Edmonds, R. L., Monson, R. K., Ollinger, S. V., Pallardy, S. G., Pregitzer, K. S., Todd, D. E., 2011. Mercury distribution across 14 US forests. Part I: Spatial patterns of concentrations in biomass, litter, and soils. Environmental Science \& Technology $\mathbf{4 5}$, 3974-3981.

Obrist, D., Moosmüller, H., Schürmann, R., Chen, L. W. A., Kreidenweis, S. M., 2007. Particulate-phase and gaseous elemental mercury emissions during biomass combustion: Controlling factors and correlation with particulate matter emissions. Environmental Science \& Technology 42, 721-727.

Obrist D., Pearson, P., Webster, J.P., Kane,, T., Aiken, G.A., Alpers, C.N., 2016. Terrestrial mercury in the Western United States: Above ground biomass and soil $\mathrm{Hg}$ concentrations and distributions. Science of the Total Environment This isssue.

Parsons, A., 2003. Burned area emergency rehabilitation (BAER) soil burn severity definitions and mapping guidelines. USDA Forest Service, Rocky Mountain Research Station. (Missoula, MT) Available online:

http://www.fws.gov/fire/ifcc/esr/Remote\%20Sensing/soil_burnsev_summary_guide0422 03.pdf. Accesses 23 January 2016.

Pirrone, N., Cinnirella, S., Feng, X., Finkelman, R. B., Friedli, H. R., Leaner, J., Mason, R., Mukherjee, A. B., Stracher, G. B., Streets D. G., Telmer, K., 2010. Global mercury emissions to the atmosphere from anthropogenic and natural sources. Atmospheric Chemistry and Physics 10, 5951-5964.

Pokharel, A. K., Obrist, D., 2011. Fate of mercury in tree litter during decomposition. Journal of Geophysical Research: Biogeosciences 8, 2507-2521.

Poulin J., Gibb, H., 2008. Mercury: Assessing the environmental burden of disease at national and local levels. Editor, Prüss-Üstün A. WHO Environmental Burden of Disease Series No. 16. World Health Organization, Geneva. Available online: http://www.who.int/quantifying_ehimpacts/publications/ebd16/en/. Accessed 23 January 2015.

Rea, A. W., Lindberg, S. E., Keeler, G. J., 2000. Assessment of dry deposition and foliar leaching of mercury and selected trace elements based on washed foliar and surrogate surfaces. Environmental Science \& Technology 34, 2418-2425.

Rea, A. W., Lindberg, S. E., Keeler, G. J., 2001. Dry deposition and foliar leaching of mercury and selected trace elements in deciduous forest throughfall. Atmospheric Environment 35, 3453-3462.

Rea, A. W., Lindberg, S. E., Scherbatskoy, T., Keeler, G. J., 2002. Mercury accumulation in foliage over time in two northern mixed-hardwood forests. Water, Air, and Soil Pollution 133, 49-67.

Reinhardt, E. D., Keane, R. E., Brown, J. K., 1997. First order fire effects model: FOFEM 4.0, user's guide. USDA Forest Service General Technical Report INT-GTR-344. Available online: http://www.treesearch.fs.fed.us/pubs/25257. Accessed 23 January 2015.

Rutter, A. P., Schauer, J. J., Shafer, M. M., Creswell, J. E., Olson, M. R., Robinson, M., Collins, R. M., Parman, A. M., Katzman, T. L., Mallek, J. L., 2011. Dry deposition of gaseous 
elemental mercury to plants and soils using mercury stable isotopes in a controlled environment. Atmospheric Environment 45, 848-855.

Selin, N. E., 2009. Global biogeochemical cycling of mercury: A review. Annual Review of Environment and Resources 34, 43-63.

Selin, N. E., Jacob, D. J., Park, R. J., Yantosca, R. M., Strode, S., Jaeglé, L., Jaffe, D., 2007. Chemical cycling and deposition of atmospheric mercury: Global constraints from observations. Journal of Geophysical Research: Atmospheres 112, 1-14.

Skyllberg, U., Bloom, P. R., Qian, J., Lin, C. M., Bleam, W. F., 2006. Complexation of mercury (II) in soil organic matter: EXAFS evidence for linear two-coordination with reduced sulfur groups. Environmental Science \& Technology 40, 4174-4180.

Skyllberg, U., Xia, K., Bloom, P. R., Nater, E. A., Bleam, W. F., 2000. Binding of mercury (II) to reduced sulfur in soil organic matter along upland-peat soil transects. Journal of environmental quality 29, 855-865.

Smith, D. B., Cannon, W. F., Woodruff, L. G., Solano, F. Kilburn, J. E., Fey, D. L., 2013. Geochemical and Mineralogical Data for Soils of the Conterminous United States. U.S. Geological Survey Reston, VA, USA. Available online: http://pubs.usgs.gov/ds/801/. Accessed 23 January 2016.

St. Louis, V. L., Rudd, J. W., Kelly, C. A., Hall, B. D., Rolfhus, K. R., Scott, K. J., Lindberg, S. E., Dong, W., 2001. Importance of the forest canopy to fluxes of methyl mercury and total mercury to boreal ecosystems. Environmental Science \& Technology 35, 3089-3098.

Thompson, R. S., Anderson, K. H., Bartlein, P. J., 1999. Atlas of relations between climatic parameters and distributions of important trees and shrubs in North America. US Department of the Interior, US Geological Survey. Professional Paper 1650-A,B Available online: http://pubs.usgs.gov/pp/p1650-a/. Accessed 23 January 2016.

Westerling, A. L., Hidalgo, H. G., Cayan, D. R., Swetnam, T. W., 2006. Warming and earlier spring increase western US forest wildfire activity. Science 313, 940-943.

Westerling, A., Brown, T., Schoennagel, T., Swetnam, T., Turner, M., Veblen, T., 2014. Briefing: Climate and wildfire in western US forests, in: Sample, V. A, Bixler, R. P. (Eds.), Forest conservation and management in the Anthropocene: Conference proceedings. Proceedings. RMRS-P-71. Fort Collins, CO: US Department of Agriculture, Forest Service. Rocky Mountain Research Station. pp. 81-102. Available online: http://www.treesearch.fs.fed.us/pubs/46580. Accessed 23 January 2016.

Wiedinmyer, C., Friedli, H. 2007. Mercury emission estimates from fires: An initial inventory for the United States. Environmental Science \& Technology 41, 8092-8098.

Wiedinmyer, C., Quayle, B., Geron, C., Belote, A., McKenzie, D., Zhang, X., O’Neill, S., Wynne, K. K., 2006. Estimating emissions from fires in North America for air quality modeling. Atmospheric Environment 40, 3419-3432.

Woodruff, L. G., Cannon, W. F., 2010. Immediate and long-term fire effects on total mercury in forests soils of northeastern Minnesota. Environmental Science \& Technology 44, 53715376.

Xia, K., Skyllberg, U. L., Bleam, W. F., Bloom, P. R., Nater, E. A., Helmke, P. A., 1999. X-ray absorption spectroscopic evidence for the complexation of $\mathrm{Hg}$ (II) by reduced sulfur in soil humic substances. Environmental Science \& Technology 33, 257-261. 
Table 1: Individual tree species included in the thirteen major forest types. The mixed conifer group consists of regions where all groups included occupy significant portions of an area, but no single group covers the majority of the area.

\begin{tabular}{|c|c|}
\hline Forest Type & Species Included \\
\hline Aspen & Populus tremuloides, quaking aspen \\
\hline Desert scrub & Prosopis juliflora, mesquite \\
\hline Douglas fir & Pseudotsuga menziesii, doulas fir \\
\hline $\begin{array}{l}\text { Hemlock/sitka } \\
\text { spruce }\end{array}$ & $\begin{array}{l}\text { Tsuga heterophylla, western hemlock } \\
\text { Thuja plicata, western redcedar } \\
\text { Picea sitchensis, sitka spruce }\end{array}$ \\
\hline Lodgepole pine & Pinus contorta, lodgepole pine \\
\hline $\begin{array}{l}\text { Other western } \\
\text { softwoods }\end{array}$ & $\begin{array}{l}\text { Pinus strobiformis, southwestern white } \\
\text { pine } \\
\text { Pinus flexilis, limber pine } \\
\text { Pinus aristata, bristlecone pine } \\
\text { Pinus albicaulis, whitebark pine }\end{array}$ \\
\hline Pinyon/juniper & $\begin{array}{l}\text { Juniperus occidentalis, western juniper } \\
\text { Juniperus osteosperma, Utah juniper } \\
\text { Pinus edulis, pinyon } \\
\text { Juniperus scopulorum, Rocky Mountain } \\
\text { juniper }\end{array}$ \\
\hline Ponderosa pine & $\begin{array}{l}\text { Pinus ponderosa, ponderosa pine } \\
\text { Libocedrus decurrens, incense cedar } \\
\text { Pinus jeffreyi, jeffrey pine }\end{array}$ \\
\hline Spruce/fir & $\begin{array}{l}\text { Abies concolor, White fir } \\
\text { Abies grandis, grand fir } \\
\text { Abies lasiocarpa, Subalpine fir } \\
\text { Picea pungens, blue spruce } \\
\text { Picea engelmannii, Engelmann spruce } \\
\text { Abies amabilis, Pacific silver fir }\end{array}$ \\
\hline Western larch & Larix occidentalis, Western Larch \\
\hline Western oaks & $\begin{array}{l}\text { Quercus agrifolia, California live Oak } \\
\text { Quercus chrysolepis, canyon live oak } \\
\text { Quercus douglasii, blue oak } \\
\text { Quercus gambelii, gambel oak } \\
\text { Quercus garryana, Oregon white oak } \\
\text { Quercus wislizeni, interior live oak } \\
\text { Quercus turbinella, shrub live oak }\end{array}$ \\
\hline $\begin{array}{l}\text { Western white } \\
\text { pine }\end{array}$ & Pinus monticola, western white pine \\
\hline Mixed conifer & $\begin{array}{l}\text { other western softwoods, spruce/fir, } \\
\text { lodgepole pine, douglas fir }\end{array}$ \\
\hline
\end{tabular}

